\title{
ZASADA PROPORCJONALNOŚCI W TWORZENIU PRAWA ADMINISTRACYJNEGO
}

\section{WPROWADZENIE}

Możliwość ustanawiania praw i obowiązków administracyjnych jednostki zawsze wystawiała na pokusę stanowiących prawo ${ }^{1}$. Jednakże koncepcja państwa prawa ustanawia imperatyw, zgodnie z którym prawodawca powinien podejmować środki adekwatne do planowanych celów, a wspomniana zasada wyznacza granice władzy prawodawczej - stając się swoistym zabezpieczeniem². Jak zaznaczyła Joanna Zakolska:

gdyby rzeczywistość odzwierciedlała teoretyczne modele [...], istnienie takich zasad, jak zasada proporcjonalności, byłoby niepotrzebne. Prawodawca zawsze tworzyłby prawo obiektywnie i subiektywnie dobre, realizując słuszne cele, a metody służące osiagnięciu tych celów nie budziły zastrzeżeń ani osób zainteresowanych, ani obserwatorów z zewnątrz³.

Opisywana zasada jest więc relewantnym kryterium oceny konstytucyjności i legalności poczynań organów władzy publicznej, przez co wzmacnia ochronę praw oraz wolności jednostki ${ }^{4}$.

Obecnie - w prawie administracyjnym - prawodawstwo staje się dominującym instrumentarium regulowanie stosunków społecznych i gospodarczych, procesem, w trakcie którego ad hoc rozstrzyga się dylematy związane ze stanowieniem prawa, którego przedmiotem jest państwo i egzystujące w nim jednostki, a jego efekty są wypadkową czynników pozanormatywnych, przy tym pełne osiagnięcie celów zakładanych przez prawodawcę bywa rzadkością, w konsekwencji czego podejmuje się próby nowelizacyjne ${ }^{5}$. Jak więc rozstrzygnąć następującą sprzeczność:

${ }^{1}$ Por. J. Zakolska, Zasada proporcjonalności w orzecznictwie Trybunatu Konstytucyjnego, Warszawa 2008, s. 5.

${ }^{2}$ Zob. P. Krawczyk, Rola zasady proporcjonalności w wyznaczaniu granic prawa własności, „Krytyka Prawa. Niezależne Studia nad Prawem” 1, 2009, nr 1, s. 275.

${ }^{3}$ J. Zakolska, op. cit., s. 6.

${ }^{4}$ Z. Kmieciak, Ogólne zasady prawa i postępowania administracyjnego, Warszawa 2000, s. 113.

${ }^{5}$ Por. M. Kamiński, Zasada ochrony zaufania jednostki do obowiazywania i kontynuacji (ciagtości) treściowej norm ustawowych a hipertrofia zmian normatywnych w prawie administracyjnym, w: P. J. Suwaj (red.), Inflacja prawa administracyjnego, Warszawa 2012, s. 45. Także J. Zimmermann, O kryzysie prawa administracyjnego, „Casus” 2013, nr 67, s. 7-8; D. Dąbek, Prawo sędziowskie w polskim prawie administracyjnym, Warszawa 2010, s. 283-291; J. Strzelecki, Niedoskonałość rozwiqzań prawnych a sytuacje patologiczne w administracji publicznej, w: P. J. Suwaj, D. R. Kijowski (red.), Patologie w administracji publicznej, Warszawa 2012, s. 170; Ł. Folak, Instrumen- 
1) prawodawca, stanowiąc normy prawa administracyjnego, korzysta ze swobody regulacyjnej, a celowość i trafność przyjmowanych rozwiązań nie może być kompleksowo oceniana przez sądownictwo ze względu na zasadę podziału władz, niemniej

2) prawodawca ten niejednokrotnie przekracza zakres przyznanej mu swobody regulacyjnej (tworząc normy nieracjonalne, niekoherentne, nieadekwatne, znacznie ograniczające prawa i wolności obywateli)?

Zasięg oddziaływania zasady proporcjonalności obejmuje nie tylko proces stosowania prawa administracyjnego, lecz również etap jego tworzenia ${ }^{6}$. Nadto, jak wskazuje się w judykaturze, każde działanie władzy administracyjnej $\mathrm{w}$ demokratycznym państwie prawnym podporządkowane musi być zasadzie proporcjonalności ${ }^{7}$, a zasada ta ma szerokie znaczenie - odnosi się do ogółu sytuacji, w których państwo za pomocą stanowionego przez siebie prawa oddziałuje na podmioty pozostajace pod jego władzą. W jakiej mierze zasada proporcjonalności legislacyjnej może być pomocna oraz wykorzystywana podczas procesu prawodawczego i przeciwdziałać nieprawidłowościom w stanowieniu prawa administracyjnego?

\section{FILOZOFICZNE ODNIESIENIA DO PROPORCJONALNEGO TWORZENIA PRAWA ADMINISTRACYJNEGO}

W mojej ocenie można przeprowadzić eksperyment myślowy i - bioracc za kryterium proporcjonalność (wyważenie relacji między celem a środkiem) wyodrębnić dwa modele tworzenia prawa administracyjnego: model proporcjonalnego tworzenia prawa administracyjnego i model instrumentalnego tworzenia prawa administracyjnego.

\section{Model proporcjonalnego tworzenia prawa administracyjnego}

Zgodnie z myślą Arystotelesa:

każdy, kto się rozumie na rzeczy, unika nadmiaru i niedostatku, szuka natomiast środka i środek wybiera, i to nie środek samej rzeczy, lecz środek ze względu na nas. [...] dzielność musi zmierzać do owego właściwego środka jako do swego celu. [...] Tyle tedy wykazaliśmy, że we wszystkim chwalebna jest trwała tendencja do zachowania środka, że jednakowoż [niekiedy] odbiegać odeń należy już to w kierunku nadmiaru, już to w kierunku niedostatku; w ten bowiem sposób najłatwiej utrafimy w środek i w to, co jest dobre ${ }^{9}$.

talizacja prawa administracyjnego, w: A. Błaś (red.), Antywartości w prawie administracyjnym. VI Krakowsko-Wrocławskie Spotkanie Naukowe Administratywistów, Warszawa 2016, s. 368-373 i cytowana tam literatura.

${ }^{6}$ Z. Duniewska, Zasada proporcjonalności, w: M. Stahl (red.), Prawo administracyjne. Pojęcia, instytucje, zasady w teorii i orzecznictwie, Warszawa 2013, s. 147-148.

${ }^{7}$ Wyrok NSA z 14 lutego 2012 r., II OSK 2249/10, Lex nr 1219099.

${ }^{8}$ Wyrok TK z 18 października 2011 r., SK 2/10, Dz. U. 2011, Nr 240, poz. 1439.

${ }_{9}$ Arystoteles, Etyka nikomachejska, w: K. Leśniak, Arystoteles, Warszawa 1975, s. 276-278. Także Arystoteles, Etyka nikomachejska. Etyka wielka. Etyka eudemejska. O cnotach i wadach, przekłady, wstępy i komentarze - D. Gromska, L. Renger, W. Wróblewski, Warszawa 2002, s. 111 i n. 
Arystotelejska koncepcja złotego środka wskazuje, że aby osiąnnąć szczęście, należy działać z umiarem i dążyć do osiagnięcia środka między skrajnościami ${ }^{10}$. W ujęciu filozofa złoty środek to rozwiązanie słuszne, zgodne z właściwa miara, którą wyznacza rozum ${ }^{11}$; należy dbać o to, by państwem kierowały ogólne normy, a nie tymczasowe uchwały ${ }^{12}$.

Arystoteles proponuje czterostopniową drogę ku zastosowaniu teorii złotego środka (która - w mojej ocenie - może być transponowana na stanowienie prawa administracyjnego): poznać samego siebie (poznać obowiązujacy stan unormowań administracyjnoprawnych w konkretnym zakresie); wyznaczyć złoty środek (określić zasadę proporcjonalności w tworzeniu prawa administracyjnego); ćwiczyć cnotę (stosować zasadę proporcjonalności w tworzeniu prawa administracyjnego); osiagnaćc trwałą dyspozycję (osiagnaćc prawidłowa praktykę legislacyjna, aż do stanu przyzwyczajenia) ${ }^{13}$.

Zatem zgodnie z koncepcją Arystotelesa należy stwierdzić, że proporcjonalny model tworzenia prawa administracyjnego kładzie nacisk na adekwatność celu i środków potrzebnych do realizacji zamierzenia. Przy tym teoria ta koncentruje się na odpowiednich (,złotych”) środkach legislacyjnych ${ }^{14}$.

\section{Model instrumentalnego tworzenia prawa administracyjnego}

Wbrew powszechnej opinii i stosowanym uproszczeniom, Machiavelli nie jest autorem myśli, że „cel uświęca środki” ${ }^{15}$. Część twórczości florentczyka uległa szybkiej instrumentalizacji w tym właśnie sensie i implikowała dyskredytację myśli filozofa ${ }^{16}$. W swojej filozofii polityki Machiavelli używał dewizy: „należy zawsze mieć na uwadze cel”"

${ }^{10}$ R. H. Popkin, A. Stroll, Filozofia, Poznań 1994, s. 17. Także A. Sylwestrzak, Historia doktryn politycznych i prawnych, Warszawa 2013, s. 54.

${ }^{11}$ A. Andrzejuk, Człowiek i dobro, Antropologiczne podstawy etyki, s. 4, http://katedra.uksw. edu.pl/publikacje/artur_andrzejuk/czlowiek_i_dobro.pdf [dostęp: 20.04.2017].

12 M. Malmon, Arystotelesa poszukiwania idealnego ustroju państwowego, „Kultura i Wartości” 2013, nr 2(6), s. 17.

${ }^{13}$ Por. Arystoteles, Etyka nikomachejska, w: K. Leśniak, op. cit., s. 275 i n. Także Arystoteles, Etyka nikomachejska. Etyka wielka..., s. 103 i n.

${ }_{14}$ Koncepcje zbliżone do arystotelejskiej myśli prezentowali również inni filozofowie prawa. Jak akcentował Monteskiusz, prawodawca powinien kierować się duchem umiarkowania - idem, O duchu praw, tłum. T. Boy-Żeleński, Kęty 1997, s. 487. Zgodnie z poglądami jednego z ojców państwa prawa, niemieckiego jurysty R. von Mohla: „zbytnia gorliwość prawodawcza rodzi nieraz zamęt w rozkazach, niedokładne obznajomienie się obywateli i urzędników, a ostatecznie - lekceważenie”; oraz gdyby „jakaś ustawa podrzędnej stosunkowo potrzebie zadość czyniła, a wymagała jednocześnie obszernych urządzeń, dużego kosztu lub wiele czasu obywatelom zabierała, to wydanie tejże byłoby nieroztropne, choćby treść jej nie ulegała zarzutom" - idem, Encyklopedia umiejętności politycznych, tłum. A. Białecki, opr. A. Bosiacki, Warszawa 2003, s. 135. Podaję za: A. Stępkowski, Zasada proporcjonalności w europejskiej kulturze prawnej. Sadowa kontrola władzy dyskrecjonalnej w nowoczesnej Europie, Warszawa 2010, s. 53.

${ }_{15}$ M. Mariano, Konflikt polityczny i natura ludzka: Machiavellego rozważania nad starożytna Republika Rzymskq i nowożytna Florencja oraz ich wptyw na współczesna świadomośc demokratyczna, „Ethics in Progress Quarterly”3(1), 2012, s. 113.

${ }_{16}$ Por. A. Riklin, Niccolo Machiavellego nauka o rzqdzeniu, Poznań 2000, s. 36

17 M. Mariano, op. cit., s. 113-114. 
W dziele $K$ sia $\dot{z} e^{18}$ filozof zawarł tezę, że największą namiętnością człowieka jest władza sprawowana dla niej samej, a cnota to zbiór nawyków, które umożliwiają osiagnięcie celów ${ }^{19}$. Zatem kalkulowanie celów i środków w polityce jest właściwe i przydatne, ponieważ polityka dotyczy uwzględniania interesów państwa, przy tym cele polityki nie sa dyktowane przez moralność, lecz efektywność środków ${ }^{20}$, a nadrzędną wartością jest tzw. racja stanu ${ }^{21}$ lub dobro wspólne ${ }^{22}$.

Tak więc w świetle koncepcji Machiavellego można przyjąć, że instrumentalny model tworzenia prawa administracyjnego kładzie nacisk na realizację założonych celów, nawet z pominięciem proporcjonalnych środków. Teoria ta wyraża supremację (,żelaznego”) celu, jaki chce osiagnaćc prawodawca ${ }^{23}$.

\section{RACJONALNOŚĆ PRAWODAWCY I POPRAWNA LEGISLACJA A ZASADA PROPORCJONALNOŚCI}

Zasada proporcjonalności stała się instrumentem kontroli, po który coraz częściej sięga sądownictwo konstytucyjne i administracyjne, wskazując, iż jest ona jedną z zasad kardynalnych poprawnej legislacji, wynikających z zasady demokratycznego państwa prawnego ${ }^{24}$. Postulatom proporcjonalności w tworzeniu prawa administracyjnego odpowiada model racjonalnego tworzenia prawa - zaproponowany przez Jerzego Wróblewskiego - który składa się z następujących determinant: założenie dostatecznie sprecyzowanego celu; ustalenie prawidłowości określających powiązania między celem a zjawiskami prowadzacymi do celu (potencjalne środki realizacji celu); wskazanie, które ze środków realizacji celu są środkami prawnymi (prawne środki realizacji celu); wybór prawnego środka realizacji założonego celu; ustanowienie unormowań prawa powszechnie obowiązującego ${ }^{25}$.

${ }_{18}$ N. Machiavelli, Ksią̇ę, tłum. A. Klimkiewicz, Kraków 2005; idem, Ksiażę. Cel uświęca środki, tłum. Z. Płoski, Gliwice 2010.

${ }_{19}$ D. Prońko, Wtadza i władca wedtug dzieła Księżę Niccola Machiavellego, „Ludzie, Zarządzanie, Gospodarka, Studia i Materiały. Miscellanea Oeconomicae” 17, 2013, nr 1, s. 345-346.

${ }^{20}$ Por. A. Sylwestrzak, op. cit., s. 136-137.

21 A. Riklin, op. cit., s. 31 i 58. Także A. Gugnin, T. Pliszka, Instytucjonalny wymiar etyki w ujęciu Niccola Machiavellego, s. 122, http://ur.edu.pl/pliki/Zeszyt15/10.pdf [dostęp: 10.12.2017].

${ }^{22}$ A. Riklin, op. cit., s. 68.

${ }^{23}$ Koncepcje zbliżone do machiawelicznej myśli w zakresie proporcjonalności legislacyjnej, prezentowali również inni filozofowie prawa. Jak akcentował J. J. Rousseau, wszelkie poczynania demokratycznego ustawodawcy są afirmacją wolności obywateli, stąd prawodawca nie jest związany żadnymi zasadami - zob. idem, Umowa społeczna, Łódź 1948, s. 23-24. Zgodnie z poglądem I. Kanta wola prawodawcy ustalającego unormowania jest wolą niedopuszczającą krytyki, wolną od zarzutu - por. idem, Metaphysische Anfangsgründe der Rechtslehre, Königsberg 1797, F. Nicolovius s. 170 (s. 123); W. Buchner, Kant - państwo i prawo, Kraków 1996, s. 111. Podaję za: A. Stępkowski, Zasada proporcjonalności..., s. 34.

${ }^{24}$ L. Garlicki, Przesłanki ograniczania konstytucyjnych praw $i$ wolności (na tle orzecznictwa Trybunału Konstytucyjnego), „Państwo i Prawo” 56, 2001, z. 10, s. 7; J. Zakolska, op. cit., s. 252.

25 J. Wróblewski, Teoria racjonalnego tworzenia prawa, Wrocław 1985, s. 134-135. 
Zasada proporcjonalności ustanawia normę optymalizacyjną - stosowanie tejże zasady przy ocenie zakresu regulacji i uciążliwości ingerencji wymaga uwzględnienia poprzednio obowiąujących norm prawnych, co pozwala na kształtowanie długofalowej polityki legislacyjnej ${ }^{26}$.

W literaturze dostrzega się ścisły związek i zależność pomiędzy zasada poprawnej legislacji i zasadami techniki prawodawczej. Jak zaznaczono w piśmiennictwie:

Funkcją zasady (zasad) poprawnej legislacji nie jest tylko zapewnienie prawidłowości prawu regulującemu stosunki między władzami publicznymi i obywatelami (jednostkami), lecz w ogólności prawu, któremu jest konieczna do osiagnięcia celów wyznaczonych danemu uregulowaniu. Ponad wszelką wątpliwość pozostaje, że na czoło wysuwa się zagwarantowanie pewności i bezpieczeństwa prawnego obywatelom, dlatego z zasady tej wynika zakaz stanowienia przepisów, które pozostawiają organom państwowym zbyt dużą swobodę oraz umożliwiają dowolność rozstrzygnięć (K 33/05 z 17 maja 2006 r.). [...] Pojęcie zasad poprawnej legislacji jest pokrewne pojęciu zasad techniki prawodawczej (skodyfikowanych w rozporządzeniu RM z 20 czerwca 2002 r., Dz. U. Nr 100, poz. 908), ale nie jest z nim tożsame. Nie każde bowiem, lecz tylko istotne, naruszenie zasad techniki prawodawczej stanowi równocześnie złamanie konstytucyjnych zasad (zasady) prawidłowej legislacji27.

Aktem wyznaczajacym dyrektywy legislacyjne w polskim porządku prawnym jest rozporządzenie Prezesa Rady Ministrów z 20 czerwca 2002 r. w sprawie „Zasad techniki prawodawczej”"28. Omawiane zasady stanowią wskazówki

${ }^{26}$ P. Krawczyk, op. cit., s. 293.

${ }_{27}$ M. Zubik, W. Sokolewicz, Komentarz do art. 2 Konstytucji RP, teza 40, w: L. Garlicki, M. Zubik (red.) et al., Konstytucja Rzeczypospolitej Polskiej. Komentarz, t. 1, Warszawa 2016, wyd. 2, Lex [dostęp: 10.12.2017]. Podobnie B. Banaszak, Komentarz do art. 2 Konstytucji RP, w: Konstytucja Rzeczypospolitej Polskiej. Komentarz, wyd. 2, Warszawa 2012, Legalis [dostęp: 10.12.2017].

${ }^{28}$ T.jedn.: Dz. U. 2016, poz. 283 (dalej jako: rozporządzenie). Stosownie do $§ 1$ ust. 1 pkt 1)-3) rozporządzenia podjęcie decyzji o przygotowaniu projektu ustawy poprzedza się w szczególności: wyznaczeniem i opisaniem stanu stosunków społecznych w dziedzinie wymagającej interwencji organów władzy publicznej oraz wskazaniem pożądanych kierunków ich zmiany; analizą aktualnego stanu prawnego; ustaleniem możliwości podjęcia środków interwencji organów władzy publicznej, alternatywnych w stosunku do uchwalenia ustawy. Zgodnie z § 1 ust. 2 pkt 1)-4) oraz pkt 6) rozporządzenia w przypadku podjęcia decyzji o przygotowaniu projektu ustawy, jeżeli projekt ten nie jest opracowywany na podstawie założeń, należy w szczególności: ustalić skutki dotychczasowych uregulowań prawnych obowiązujących w danej dziedzinie; określić cele, jakie zamierza się osiagnaćc przez uchwalenie ustawy; ustalić rozwiązania prawne alternatywne, które mogą skutecznie służyć osiągnięciu założonych celów; sformułować prognozy podstawowych i ubocznych skutków zamierzonych rozwiązań prawnych alternatywnych, w tym wpływu tych rozwiązań na system prawa; dokonać wyboru optymalnego w danych warunkach rozwiąania prawnego. Jak zaakcentowała M. M. Dębska: „decyzję o przygotowaniu ustawy należy poprzedzić ustaleniem, czy rzeczywiście zachodzi konieczność wydania aktu prawnego [...]. Zachowanie tego procesu zmierza do zapewnienia racjonalności działań legislatora. [...] Pierwszą czynnością powinno być zatem określenie stanu istniejacego przez wyznaczenie i opisanie stosunków społecznych w dziedzinie wymagającej interwencji organów władzy publicznej. [...] Następnym etapem postępowania powinno być wyznaczenie pożądanych kierunków zmian, a zatem określenie tego, do czego w danym stanie rzeczy powinno się dążyć. Takie nakreślenie celów pozwala na ustalenie, jakie środki oddziaływania umożliwiają ich osiagnięcie [...]. Końcowym etapem procesu [...] jest dokonanie wyboru sposobu interwencji organów władzy publicznej, a zatem rozstrzygnięcie, czy 
legislacyjne, które winny być uwzględniane przez podmioty tworzące prawo administracyjne ${ }^{29}$. Nadto zasady techniki prawodawczej sa dyrektywami skierowanymi do prawodawcy, które wskazuja, jak poprawnie wyrażać normy prawne w przepisach prawnych, lecz nie służą one ocenie ważności obowiązujących unormowań ${ }^{30}$.

Przytoczone twierdzenia wskazuja, iż w zasadach techniki prawodawczej uwzględniono postulat proporcjonalności w tworzeniu prawa (ustalenie, czy zachodzi konieczność wydania aktu normatywnego, określenie środków adekwatnych do realizacji zakładanych celów oraz umożliwiających ich osiagnięcie).

\section{ZASADA PROPORCJONALNOŚCI I ZASADY PROPORCJONALNOŚCI W TWORZENIU PRAWA ADMINISTRACYJNEGO (ZASADY PROPORCJONALNOŚCI LEGISLACYJNEJ)}

\section{Zasada proporcjonalności $\mathrm{w}$ prawie administracyjnym}

Istotą zasady proporcjonalności jest miarkowanie działań organów administracji publicznej oraz minimalizacja ich ingerencji w sferę praw i wolności jednostki, a także konieczność dopasowania środków działania podejmowanych przez władzę publiczną do założonych celów oraz wymóg wyważenia interesu publicznego oraz interesów podmiotów prywatnych ${ }^{31}$. Innymi słowy,

konieczne jest przygotowanie projektu ustawy, czy też właściwsza będzie inna forma działania. [...] niewątpliwie proces postępowania [...] polega na wyłonieniu - najlepszego z możliwych - rozwiązania prawnego, umożliwiającego zrealizowanie zamierzonego celu. Komentowane rozporządzenie w tym przypadku posługuje się pojęciem rozwiązania optymalnego, a zatem takiego, które najpełniej realizuje zamierzone cele przy możliwie najmniejszym obciążeniu budżetu państwa oraz społeczeństwa” - eadem, Komentarz do $\$ 1$ zatacznika rozporzadzenia $w$ sprawie „Zasad techniki prawodawczej”, w: Zasady techniki prawodawczej. Komentarz, Lexis Nexis 2013, wyd. 1, Lex [dostęp: 10.12.2017].

${ }^{29}$ Wyrok NSA z 21 marca 2012 r., I OSK 464/11, Lex nr 1295814. Zob. także wyrok NSA z 9 maja 2013 r., I GSK 208/12, Lex nr 1343861; wyrok NSA z 23 lutego 2016 r., I OSK 3118/15, Lex nr 2114265; wyrok SN z 15 czerwca 2012 r., II CSK 436/11, Lex nr 1232234.

${ }^{30}$ Wyrok NSA z 5 maja 2011 r., I OSK 1059/10, Lex nr 990131. Jak zaznaczył TK w wyroku z 12 grudnia 2006 r., sygn. akt P 15/05, Dz. U. 2006, Nr 231, poz. 1688: „Należy zwrócić uwagę, że zasady techniki prawodawczej sa regułami konstruowania poprawnych aktów normatywnych i rzetelnego dokonywania zmian w systemie, wiążącymi rządowego prawodawcę. Także ustawodawca nie powinien od tych zasad odstępować. Nierzadko, w następstwie błędów w technice prawodawczej, rozwiązania aktu normatywnego stają się tak dalece wadliwe, że naruszają standardy prawodawstwa w państwie prawa. Z wyrażonej w art. 2 Konstytucji klauzuli demokratycznego państwa prawnego doktryna i orzecznictwo wyprowadzaja m.in. wymagania co do techniki legislacyjnej, określane jako zasady przyzwoitej (poprawnej) legislacji. Stąd w wielu orzeczeniach Trybunał Konstytucyjny odwołuje się subsydiarnie do zasad techniki prawodawczej, a niejednokrotnie niepoprawne sformułowanie aktu prawnego (przepisu) skutkuje stwierdzeniem jego niekonstytucyjności, zwłaszcza gdy prowadzi do naruszenia praw i wolności konstytucyjnych bądź jest źródłem poważnych problemów ze stosowaniem prawa”.

${ }^{31}$ K. Wojtyczek, Zasada proporcjonalności, w: B. Banaszak, A. Preisner (red.), Prawa i wolności obywatelskie w Konstytucji RP, Warszawa 2002, s. 669; A. Frąckowiak-Adamska, Zasada 
zasada ta - stanowiąc limit dla wprowadzanych przez ustawodawcę ograniczeń - wskazuje, aby między celem regulacji a wynikającymi z unormowania środkami zachowana była stosowna oraz uzasadniona adekwatnośćc ${ }^{32}$. Jak zaznaczyła Zofia Duniewska:

Zasada proporcjonalności - w jej szerokim rozumieniu - nakazuje, aby między celem regulacji prawnej lub indywidualnej ingerencji władzy publicznej (ustawodawczej, wykonawczej i sądowniczej) a przewidzianymi prawem środkami postępowania zachowana była korelacja i optymalne proporcje ${ }^{33}$.

Przyjmuje się, iż zasada proporcjonalności ma charakter uniwersalistyczny, o czym świadczy powszechna potrzeba zachowania równowagi pomiędzy ingerencją czynioną w imię interesu publicznego i wartością zakładanego celu (stosowanie tej zasady zmierza do wyważenia jak najlepszej proporcji w relacji środek-cel) $)^{34}$.

Z zasadą proporcjonalności wiążą się nakazy:

1) przydatności (środek winien być przydatny do realizacji danego celu; w świetle posiadanej przez prawodawcę wiedzy uzasadnione jest możliwe skuteczne i efektywne zrealizowanie założonych zamiarów legislacyjnych);

2) konieczności (nieodzowne jest indywidualizowanie ingerencji prawodawczej oraz sprowadzenie jej do poziomu najłagodniejszego; obowiązkiem ustawodawcy jest zastosowanie ograniczenia najmniejszego, ale zarazem wystarczającego dla osiagnięcia celu, co wiąże się także z brakiem wykraczania przez podjęta ingerencję poza działania niezbędne do realizacji celu);

3) proporcjonalności sensu stricto (powinna być utrzymana właściwa relacja między celem działania a ciężarem i dolegliwościami stosowanych środków - co oznacza konieczność zachowania proporcji pomiędzy ograniczeniem danego prawa lub wolności i zamierzonym pozytywnym efektem danej regulacji prawnej, a także wyważenia interesu indywidualnego oraz interesu publicznego) $)^{35}$.

\section{Zasada proporcjonalności $\mathrm{w}$ tworzeniu prawa administracyjnego (zasada proporcjonalności legislacyjnej)}

Tworzenie prawa administracyjnego następuje poprzez działania w zakresie tzw. legislacji administracyjnej, która jest rozumiana jako stanowienie, przez legitymowane podmioty, unormowań prawa administracyjnego umiesz-

\footnotetext{
proporcjonalności jako gwarancja swobód rynku wewnętrznego Wspólnoty Europejskiej, Warszawa 2009, s. 24. Także wyroki NSA z 16 grudnia 2009 r., I FSK 1172/08, Lex nr 575019, oraz z 23 marca 2011 r., I FSK 764/10, CBOSA; wyrok WSA w Białymstoku z 12 kwietnia 2011 r., I SA/ Bk 85/11, Lex nr 990441.

32 J. Zakolska, op. cit., s. 9-10.

${ }^{33}$ Z. Duniewska, op. cit., s. 144-145.

${ }^{34}$ Z. Kmieciak, Ogólne zasady prawa..., s. 111.

${ }^{35}$ Por. ibidem, s. 112-113. Także J. Zakolska, op. cit., s. 18-28; Z. Duniewska, Zasada proporcjonalności, w: M. Stahl (red.) et al., Prawo administracyjne. Pojęcia, instytucje, zasady w teorii i orzecznictwie, Warszawa 2013, s. 144-145; J. Zimmermann, Prawo administracyjne, Warszawa 2014, s. 131-132.
} 
czonych w aktach prawodawczych o zróżnicowanym charakterze i zasięgu ${ }^{36}$. Zgodnie z podobną definicją legislacja ta to zespół zasad, form, technik, a także trybów stanowienia oraz ogłaszania aktów prawnych przez podmioty administracji publicznej, a także ich uczestnictwo przy tworzeniu prawa przez inne podmioty władzy publicznej ${ }^{37}$.

Zasada proporcjonalności stanowi zawężenie zakresu swobody prawodawcy - nawet jeżeli użyte środki (skutek legislacji) sa przydatne i konieczne dla osiagnięcia założonego celu - nie można ich zastosować, jeżeli nie jest to usprawiedliwione wagą oraz charakterem tegoż celu ${ }^{38}$. Prawo administracyjne za pomocą właściwych dla tejże gałęzi środków regulacyjnych i perswazyjnych realizuje rozmaite cele, a w szczególności ma służyć dobru wspólnemu (lub interesowi publicznemu), właściwie wyważonemu z innymi chronionymi interesami $^{39}$. Jak zaznaczono w literaturze, cele prawa administracyjnego korespondują z obowiązkiem organów wyposażonych w kompetencję administracyjna do realizacji i przestrzegania interesu publicznego oraz stanowia sprecyzowanie celów zdeterminowanych konstytucyjnie w odniesieniu do określonej sfery życia społecznego. Przy tym wymiernie cele państwa i działalności prawotwórczej jego organów pozwala określić właśnie zasada proporcjonalności ${ }^{40}$. Cel publiczny, jeśli jest prawnie dozwolony i ma oparcie aksjologiczne w Konstytucji, usprawiedliwia ograniczenie danego prawa ${ }^{41}$. Precyzyjne ustalenie i wyznaczenie celów prawa administracyjnego wiąże się z koncepcją ograniczonych uprawnień prawodawczych ${ }^{42}$. Rozwijając tę koncepcję, należy stwierdzić, iż prawodawca administracyjny może wprowadzać nowe przepisy prawa jedynie, gdy nie naruszają one przepisów wyższego rzędu (np. przepisów Konstytucji RP); przechodzą one pozytywnie test zasady proporcjonalności legislacyjnej (są zgodne z treścią tej zasady). Zasada proporcjonalności w tworzeniu prawa administracyjnego jest dyrektywą nakazująca wprowadzenie do porządku prawnego danego unormowania jedynie wówczas, gdy:

1) jest niezbędna dla ochrony interesu publicznego;

2) kształtuje regulacje w sposób umożliwiający osiagnięcie założonych skutków;

${ }^{36}$ M. Stahl, Z. Duniewska, Legislacja administracyjna - zagadnienia wprowadzajace, w: M. Stahl, Z. Duniewska (red.), Legislacja administracyjna. Teoria, orzecznictwo, praktyka, Warszawa 2012, s. 22.

37 T. Bąkowski, w: idem (red.), Zarys legislacji administracyjnej. Uwarunkowania $i$ zasady prawotwórczej działalności administracji publicznej, Wrocław 2010, s. 15; T. Bąkowski, Sądowa kontrola legislacji administracyjnej pod względem zgodności z Zasadami techniki prawodawczej, w: M. Stahl, Z. Duniewska (red.), Legislacja administracyjna..., s. 37.

38 A. Walaszek-Pyzioł, Zasada proporcjonalności w orzecznictwie Trybunału Konstytucyjnego, „Przegląd Ustawodawstwa Gospodarczego” 1995, nr 1, s. 16; S. Jędrzejewski, D. R. Kijowski, Glosa do wyroku z 12 I 1999 r., P 2/98, „Państwo i Prawo” 56, 2001, z. 3, s. 106.

${ }^{39}$ M. Stahl, Z. Duniewska, Legislacja administracyjna..., w: eaedem (red.), Legislacja administracyjna..., s. 29.

40 W. Jakimowicz, Wykładania w prawie administracyjnym, Kraków 2006, s. 168-170 i cytowana tam literatura.

41 J. Zakolska, op. cit., s. 30.

${ }^{42}$ Por. K. Pałecki, Zmiany społeczne a zmiany w prawie, w: L. Leszczyński (red.), Aksjologia, konstytucja, integracja europejska, Lublin 1999, s. 20. 
3) utrzymane sa proporcje pomiędzy efektami uregulowania a ciężarami i niedogodnościami dla jednostek ${ }^{43}$.

Zasadę proporcjonalności w stanowieniu prawa administracyjnego można zdefiniować w ujęciu wertykalnym (dotyczącym ustanawiania obowiązków i ograniczania praw podmiotowych), jako normę postępowania kierowaną do prawodawcy, aby spośród możliwych środków działania wybierał możliwie najmniej uciążliwe dla podmiotów, wobec których mają być zastosowane, lub dolegliwe w stopniu nie większym niż jest to niezbędne do osiagnięcia założonego celu ${ }^{44}$. Każda wprowadzana regulacja administracyjnoprawna wymaga rzetelnej, kompleksowej i wielookresowej analizy korzyści i ograniczeń (ciężarów), jakie są z nią związane ${ }^{45}$. Podstawą normatywna zasady proporcjonalności w ujęciu wertykalnym jest art. 31 ust. 3 ustawy z 2 kwietnia 1997 r. - Konstytucja $\mathrm{RP}^{46}$.

Natomiast zasada proporcjonalności w ujęciu horyzontalnym odnosić się będzie do wyważenia celów i środków regulacji w ogólności, bez odnoszenia się do ustanawiania obowiązków lub ograniczanie praw i wolności jednostek. Zasada proporcjonalności winna być w tym zakresie miarą wszystkich działań prawodawczych i nakazuje prawodawcy np. wprowadzenie przepisów przejściowych przy zmianie stanu prawnego ${ }^{47}$. Podstawę normatywną zasady proporcjonalności w ujęciu horyzontalnym stanowi art. 2 Konstytucji RP $\mathrm{R}^{48}$.

Niedopełnienie wymogu proporcjonalności legislacyjnej w prawie administracyjnym może być stwierdzone, kiedy z wszystkich okoliczności znanych w chwili podejmowania decyzji prawodawczej wynika w sposób niewątpliwy, że dane ograniczenie nie może być środkiem przydatnym do realizacji założonego celu ${ }^{49}$.

${ }^{43}$ W. Jakimowicz, op. cit., s. 169; Z. Kmieciak, Ogólne zasady prawa..., s. 19; orzeczenie TK z 26 kwietnia 1995 r., K 11/94, OTK-A 1995, poz. 18; orzeczenie TK z 31 stycznia 1996 r., K 9/95, OTK-A 1996, nr 1, poz. 2.

${ }^{44}$ Zob. wyrok TK z 25 lutego 1999 r., K 23/98, OTK-A 1999, nr 2, poz. 25; orzeczenie TK z 31 stycznia 1996 r., K 9/95, OTK-A 1996, nr 1, poz. 2; orzeczenie TK z 20 listopada 1996 r., K 27/95, OTK-A 1996, nr 6, poz. 50.

45 S. Kasiewicz, L. Kurkliński, W. Szpringer, Zasada proporcjonalności a polski sektor bankowy. Uwarunkowania, szanse, zagrożenia, „Miesięcznik Finansowy BANK” 2013, grudzień, s. 17.

${ }^{46}$ Dz. U. Nr 56, poz. 274. Choć podstawy normatywne zasady proporcjonalności są ogólne, niejednoznaczne i rozproszone - por. J. Zakolska, op. cit.; K. Klecha, Wolność działalności gospodarczej w Konstytucji, Warszawa 2009, s. 218-220; M. Szydło, Wolność działalności gospodarczej jako prawo podstawowe, Bydgoszcz-Wrocław 2011, s. 189-244.

${ }^{47}$ K. Stern, Das Staatsrecht der Bundesrepublik Deutschland, Bd. 1: Grundbegriffe und Grundlagen des Staatrechts, Strukturprinzipen der Verfassung, München 1984, s. 864-865, oraz J. Zakolska, op. cit., s. 9-13 i cytowana tam literatura.

${ }^{48}$ Choć w literaturze wskazuje się, że podstawy normatywne zasady proporcjonalności (także w aspekcie stosowania prawa) są ogólne, niejednoznaczne i rozproszone - por. J. Zakolska, op. cit. Takie stanowisko może wynikać z wielu przepisów prawa administracyjnego będących „emanacją" ogólnej zasady proporcjonalności (np. art. 228 ust. 5 Konstytucji RP, art. 7 in fine i art. 8 § 1 ustawy z 14 czerwca 1960 r. - Kodeks postępowania administracyjnego, Dz. U. 2017, poz. 1257 ze zm.; art. 7 § 2 ustawy z 17 czerwca 1966 r. o postępowaniu egzekucyjnym w administracji, Dz. U. 2017, poz. 1201).

49 A. Walaszek-Pyzioł, op. cit., s. 16. 


\section{ZASADA PROPORCJONALNOŚCI PRAWOTWÓRCZEJ W ZNACZENIU ZEWNĘTRZNYM (ILOŚCIOWYM)}

Jednym z zasadniczych objawów nieproporcjonalnego tworzenia prawa administracyjnego jest permanentne przeregulowanie w obrębie prawa administracyjnego, mające swoje źródło w niezrozumiałym przeświadczeniu prawodawcy o nadzwyczajnej mocy sprawczej tego prawa, które ingerując w dana dziedzinę życia społecznego lub coraz szczegółowiej normując konkretne sfery stosunków, ma być tym narzędziem, które zwalczy narastające problemy oraz zapewni realizację założonych przez władzę celów politycznych, gospodarczych czy społecznych, umiejscowionych poza granicami normowania ${ }^{50}$.

Zasada proporcjonalności zewnętrznej (ilościowej) w tworzeniu prawa administracyjnego postuluje, aby prawodawca korzystał ze swoich kompetencji prawodawczych w sposób umiarkowany i ustanawiał regulacje administracyjnoprawne jedynie w zakresie koniecznym, nie generujac tzw. inflacji przepisów prawa administracyjnego ${ }^{51}$.

Inflacja prawa administracyjnego oznacza nadpodaż regulacji zewnętrznych i wewnętrznych w systemie administracji publicznej ${ }^{52}$. Inflacja prawa administracyjnego generuje dwa negatywne zjawiska: zbyt duża ilość regulacji jest trudna, czy wręcz niemożliwa, do kompetencyjnego i objętościowego objęcia przez organy administracyjne i jednostki (w mojej ocenie, z uwagi na braki organizacyjno-kadrowe w administracji publicznej oraz tempo życia społecznego); a nadto prowadzi do dalszego skomplikowania w interpretacji obowiąujących przepisów prawnych przez ich adresatów ${ }^{53}$.

Inflacja prawa administracyjnego jest konsekwencja:

1) szerokiego przedmiotu regulacji administracyjnoprawnej;

2) związku unormowań prawa administracyjnego ze zmianami politycznymi i społeczno-gospodarczymi;

3) nieustannej fluktuacji celów i zadań publicznych;

4) zmienności oraz nieuchwytności kryterium interesu publicznego;

5) rozbudowania i wielostopniowości systemu źródeł prawa administracyjnego;

6) delegowania kompetencji prawotwórczych na niejednolita grupę organów ${ }^{54}$.

${ }^{50}$ J. Jagielski, P. Gołaszewski, Kryzys prawa administracyjnego a zmiana jego paradygmatu, w: D. R. Kijowski, A. Miruć, A. Suławko-Karetko (red.), Jakość prawa administracyjnego, Warszawa 2012, s. 28 i 30; モ. Folak, op. cit., s. 368-370 i cytowana tam literatura.

${ }^{51}$ Zob. P. J. Suwaj (red.), Inflacja prawa administracyjnego, Warszawa 2012; D. Dąbek, op. cit., s. 281-283; W. Chróścielewski, Z problematyki skuteczności norm prawa administracyjnego, „Państwo i Prawo” 56, 2001, z. 4, s. 61.

${ }^{52}$ M. Możdżeń-Marcinkowski, Problematyka współzależności zjawisk inflacji $i$ kryzysu wspótczesnego prawa administracyjnego, w: P. J. Suwaj (red.), Inflacja prawa administracyjnego, Warszawa 2012, s. 17.

53 Ibidem, s. 18.

${ }^{54}$ M. Kamiński, op. cit., s. 45; Z. Kmieciak, Skuteczność regulacji administracyjnoprawnej, Łódź 1994, s. 40-41. 
Obserwowany proces inflacji prawa administracyjnego powoduje wypieranie innych regulatorów życia społecznego, co oznacza większą ilość coraz bardziej szczegółowych regulacji ${ }^{55}$. Ostatecznie wspomniana nadpodaż regulacji jest szczególnie niebezpieczna w prawie administracyjnym, które stanowi materię delikatna - obniża jego rangę i znaczenie, osłabia skuteczność unormowań, potęguje niespójność, niejednorodność oraz pozorność obowiązującego prawa $^{56}$.

\section{ZASADA PROPORCJONALNOŚCI PRAWOTWÓRCZEJ W ZNACZENIU WEWNĘTRZNYM (JAKOŚCIOWYM)}

Zasada proporcjonalności wewnętrznej (jakościowej ${ }^{57}$ ) w tworzeniu prawa administracyjnego postuluje, aby prawodawca, konstruując treść, skutki i zakres wprowadzanych unormowań, czynił to jedynie w zakresie niezbędnym dla ochrony interesu publicznego, a środki do realizacji celów prawodawczych były adekwatne, konieczne oraz właściwe ${ }^{58}$. W takim ujęciu zasada proporcjonalności w stanowieniu prawa wymaga, aby spośród możliwych i legalnych środków działania wybierać środki skuteczne do celów założonych (właściwość), pozostajace w proporcjonalnej, stosownej relacji do oczekiwanych skutków (adekwatność), a zarazem możliwie najmniej uciążliwe dla podmiotów, wobec których mają być zastosowane, lub dolegliwe w stopniu nie większym, niż jest to niezbędne dla osiagnięcia założonego celu (konieczność, nieodzowność) ${ }^{59}$.

Zasada proporcjonalności wewnętrznej (jakościowej) w tworzeniu prawa administracyjnego wskazuje, iż prawodawca: winien stosować odpowiednia formę aktu prawnego, dostosowaną do normowanej materii (zgodnie z założeniem o tzw. materii ustawowej, czy z uwzględnieniem konieczności decentralizacji procesu prawotwórczego); powinien ustanawiać stosowną prawną formę działania organów administracji publicznej (dostosowaną do wykonywanych kompetencji, realizowanych zadań); jest zobligowany do ustanawiania ade-

55 A. Stępkowski, Między sprawiedliwościa a treścia prawa stanowionego. Kształtowanie się zasady proporcjonalności $w$ orzecznictwie Trybunatu Konstytucyjnego, „Kwartalnik Prawa Publicznego" 6, 2006, nr 1, s. 109.

56 D. Dąbek, op. cit., s. 283.

57 Już w połowie XIX w. doradca kanclerza Bismarcka - Lothar Bucher - zauważył, że „fabrykacja regulacji” ma wymiar nie tylko kwantytatywny (ilościowy), ale również jakościowy. - zob. idem, Der Parlamentarismus: wie er ist, Berlin 1855, s. 196-197. Podaję za: M. Kamiński, op. cit., s. 44.

${ }^{58} \mathrm{~W}$ ocenie TK, który badał zagadnienie ustanawiania aktów prawa miejscowego (przepisów porządkowych): „konstytucyjna zasada wyłączności ustawy nie wyklucza jednak powierzenia przez ustaw organom stanowiącym samorządu terytorialnego ogólnej kompetencji do stanowienia regulacji prawnych mających na celu przeciwdziałanie zagrożeniom dla życia, zdrowia lub mienia, a także dla spokoju publicznego, pod warunkiem, że regulacje te są zgodne z zasadą proporcjonalności i nie jest możliwe skuteczne przeciwdziałanie tym zagrożeniom na gruncie istniejących unormowań ustawowych" - wyrok z 8 lipca 2003 r., P 10/02, Dz. U. 2003, Nr 134, poz. 1265.

${ }^{59}$ Orzeczenie TK z 31 stycznia 1996 r., K 9/95, OTK-A 1996, nr 1, poz. 2. J. Zakolska, op. cit., s. 63. 
kwatnych instrumentów dyskrecjonalności w prawie administracyjnym ${ }^{60}$. Źródła prawa administracyjnego obejmują wszystkie elementy w hierarchii konstytucyjnych źródeł prawa powszechnie obowiązującego. Ponadto organy administracji publicznej w szerokim zakresie prowadza działalność prawotwórczą. Ostatecznie prawo administracyjne obejmuje szereg właściwych $\mathrm{mu}$, bądź swoistych (rozporządzenia wykonawcze, akty prawa miejscowego) aktów normatywnych. Zasada proporcjonalności we wszystkich tych zakresach tworzenia prawa administracyjnego funkcjonuje i wyznacza granice prawodawstwa. Jednak z uwagi na opisane zróżnicowanie materii normatywnej jest wskazane kazuistyczne i zniuansowane badanie wpływu omawianego pryncypium na kształtowanie konkretnych źródeł prawa administracyjnego $\mathrm{w}$ znaczeniu formalnym. Zagadnienie to wymaga odrębnego wyczerpującego opracowania i tu może być jedynie zasygnalizowane.

W zakresie ujęcia zasady proporcjonalności legislacyjnej w znaczeniu wewnętrznym (jakościowym) zarysowały się dwa rozbieżne poglądy. Trybunał Konstytucyjny w swoim orzecznictwie wskazuje, że nie każde unormowanie zawierające błędne rozwiązania (niepozwalające na realizację celu, oparte na wadliwych założeniach czy ocenach społeczno-ekonomicznych) jest per se niezgodne z Konstytucją (jeżeli okaże się ono dysfunkcjonalne, to ze względu na zakres kognicji Trybunału pozostaje poza sądową kontrolą konstytucyjności stanowienia prawa) ${ }^{61}$. Dodatkowo w orzecznictwie uznaje się swobodę ustawodawcy w określaniu treści stanowionego prawa (odpowiadającego celom politycznym, gospodarczym, przemianom ustrojowym), a Trybunał podkreślał, że nie jest powołany do trafności i celowości unormowań wprowadzanych przez prawodawcę. Jednakże interwencja „negatywnego prawodawcy” ${ }^{62}$ jest uzasadniona, gdy organ stanowiący prawo „przekroczył zakres swej swobody regulacyjnej w sposób na tyle drastyczny, że naruszenie tych zasad jest ewidentne" 63 .

Zgodnie z poglądami doktryny prawa administracyjnego opartymi na wypowiedziach judykatury - fakt istnienia normy konstytucyjnej upoważniajacej do wydania danego unormowania, ograniczającego prawa i wolności, nie wystarcza do jej wprowadzenia do porządku prawnego w imię danego interesu publicznego, ponieważ jeżeli organ prawodawczy ustanowi regulacje, które z uwagi na rodzaj unormowania sa pozorne, niecelowe lub bezsensowne, należy uznać je za zakazane w świetle zasady proporcjonalności (konkretnie: wymogu przydatności) ${ }^{64}$. Choć - jak zaakcentowała Sławomira Wronkowska

${ }^{60}$ Por. P. Ruczkowski, Stosowanie przepisów dopuszczajacych różne formy luzu decyzyjnego administracji a zasada proporcjonalności, w: D. R. Kijowski, J. Radwanowcz-Wanczewska, M. Wincenciak (red.), Wyktadnia $i$ stosowania prawa administracyjnego, Warszawa 2012, s. 41-61.

${ }^{61}$ Wyrok TK z 11 maja 2007 r., K 2/07, Dz. U. 2007, Nr 85, poz. 571; wyrok TK z 7 maja 2014 r., K 43/12, Dz. U. 2014, poz. 684.

${ }^{62}$ Zgodnie z terminologia zaproponowaną przez H. Kelsena. Zob. idem, Istota i rozwój sqdownictwa konstytucyjnego, Warszawa 2009, s. 45.

${ }^{63}$ Orzeczenie TK z 9 stycznia 1996 r., K 18/95, OTK 1996, cz. I, s. 8; orzeczenie TK z 23 października 1996 r., K 1/96, OTK 1996 (5), s. 330; wyrok TK z 10 kwietnia 2006 r., SK 30/04, Dz. U. 2006, Nr 64, poz. 456.

${ }^{64}$ S. Jędrzejewski, D. R. Kijowski, op. cit., s. 106-107. 
- stanowisko sądu konstytucyjnego winno być jednoznaczne (wyrok musi jasno przesądzać, które przepisy obejmujące normy prawne przestaja obowiązywać), powściągliwe (Trybunał jest zobowiązany szanować zasadę podziału władzy i minimalizować nadmierne, negatywne skutki derogacji danego aktu prawnego), a także zachowywać wartości stanowiące podstawowe zasady prawa ${ }^{65}$.

W mojej ocenie, stosownie do zaprezentowanych ustaleń, należy opowiedzieć się za drugim z przedstawionych poglądów - zasada proporcjonalność ma wymiar pozytywny, nie stanowi jedynie ultima ratio, a jej stosowanie w legislacji administracyjnej jest uzasadnione w każdym, a nie tylko skrajnym, ewidentnym czy drastycznym przypadku.

\section{KONTROLA WYPEENIANIA WYMOGÓW PROPORCJONALNOŚCI LEGISLACYJNEJ W PRAWIE ADMINISTRACYJNYM}

Zasada proporcjonalności w prawie administracyjnym wyznacza granice dozwolonego działania organów władzy publicznej66. Konieczność stosowania wymogu proporcjonalnej relacji między celem i środkiem jest najbardziej podstawową i najwcześniejszą podstawą kontroli prawnej organów państwa ${ }^{67}$. Stosowanie zasady proporcjonalności skutkuje orzeczeniem o niekonstytucyjności istniejących lub potencjalnych aktów prawnych przekraczających ustalony poziom racjonalności, co implikuje utratę przez konkretne przepisy przymiotu mocy obowiązującej ${ }^{68}$. Zarzut naruszenia proporcjonalności legislacyjnej jest wykazany jeżeli, biorąc pod uwagę reguły kultury prawnej i racjonalności - ingerencja prawodawcza była nadmierna względem założonych celów lub cele te pozostawały poza legitymowanym w demokratycznym państwie prawa dopuszczalnym zakresem aktywności władzy ${ }^{69}$.

Jak zaakcentował Aleksander Stępkowski, kontrola stanowionego prawa z uwzględnieniem zasady proporcjonalności - polega na wyjściu poza płaszczyznę czysto formalną i orzekaniu o zawartości merytorycznej danego aktu prawnego. Stan ten prowokuje pytania o relację zasady proporcjonalności i zasady podziału władz ${ }^{70}$. Z tych powodów kontrola proporcjonalności aktów prawnych

${ }^{65}$ S. Wronkowska, Kilka uwag o „prawodawcy negatywnym”, „Państwo i Prawo” 63, 2008, z. 10 , s. 8-9.

${ }^{66}$ A. Frąckowiak-Adamska, op. cit., s. 37.

67 J. Zakolska, op. cit., s. 12.

${ }^{68}$ Zob. K. Wojtyczek, Granice ingerencji ustawodawczej w sferę praw człowieka w Konstytucji RP, Kraków 1999, s. 162; S. Wronkowska, op. cit., s. 10-11.

${ }^{69}$ Wyrok TK z 28 lutego 2003 r., K 24/02, Dz. U. 2003, Nr 38, poz. 334.

${ }^{70}$ Zasada proporcjonalności „styka się” i równoważy również z innymi zasadami prawa administracyjnego, które wyważają i limitują jej zakres oddziaływania (m.in. zasadami: równości, pomocniczości, dyskrecjonalności, zaufania do organów państwa i stanowionego prawa, sprawiedliwości, w tym sprawiedliwości proceduralnej). 
jest znaczenie trudniejsza niż ich analiza z perspektywy łatwiej weryfikowalnych kryteriów formalnych ${ }^{71}$.

Zasada proporcjonalności jest mechanizmem, na podstawie którego można eliminować z obrotu prawnego akty prawne, których obowiązywania nie można usprawiedliwiać staraniami o realizację interesu publicznego lub jeżeli nawet służą interesowi publicznemu - czynią to w sposób nadmiernie ograniczajacy prawa jednostek ${ }^{72}$.

\section{PODSUMOWANIE}

Stosowanie zasady proporcjonalności w stanowieniu prawa administracyjnego stymuluje do podejmowania racjonalnych i efektywnych regulacji; ogranicza swobodę prawodawcy; jest istotnym czynnikiem doskonalenia procesu regulacyjnego ${ }^{73}$. Zasada ta:

1) określa konieczność zachowania stosownej relacji między celami działania a zastosowanymi (lub planowanymi) do realizacji tego celu - środkami;

2) wskazuje, że prawodawca ma obowiązek stosowania najłagodniejszego środka do realizacji celu;

3) postuluje, aby ingerencja prawodawcy w prawa i wolności jednostki była dopuszczalna tylko w takim zakresie, w jakim jest to nieodzowne do ochrony uznanego za ważniejszy interesu publicznego;

4) oznacza, że działania legislacyjne winny być podejmowane jedynie, gdy założony cel nie może być zrealizowany za pomocą innych środków;

5) wymaga, aby prawodawca każdorazowo dokonywał świadomego, uzasadnionego i racjonalnego wyboru przydanych mu do dyspozycji środków działania oraz stosował środek najbardziej skuteczny z punktu widzenia realizowanego celu, a zarazem najmniej ograniczający prawa, wolności i wartości podlegajace już ochronie;

6) ustanawia konieczność, aby każda decyzja legislacyjna prawodawcy była uzasadniona z perspektywy jej nieodzowności w konkretnej materii i ze względu na czas obowiązywania ${ }^{74}$.

Zasada proporcjonalności w tworzeniu prawa administracyjnego ma charakter optymalizacyjny, a jej zastosowanie czyni każde prawo najlepszym, jakie może być ${ }^{75}$. Stosowanie tej zasady w legislacji administracyjnej stanowi gwarancję krzewienia modelu proporcjonalnego tworzenia prawa administracyjnego i odrzucenia modelu instrumentalnego. Relewantne jest również stwierdzenie, iż przestrzeganie zasady proporcjonalności w tworzeniu prawa

${ }^{71}$ A. Stępkowski, Między sprawiedliwościq..., s. 111.

${ }^{72}$ Ibidem, s. 108.

${ }^{73}$ S. Kasiewicz, L. Kurkliński, W. Szpringer, op. cit., s. 18.

${ }^{74}$ M. Wyrzykowski, Legislacja - demokratyczne państwo prawa - radykalne reformy polityczne $i$ gospodarcze, Zasada proporcjonalności, w: H. Suchocka (red.), Tworzenia prawa w demokratycznym państwie prawnym, Warszawa 1992, s. 50-51.

${ }^{75}$ Zob. D. M. Beaty, The Ulitmate Rule of Law, Oxford 2004, s. 163. Podaję za: A. Frąckowiak-Adamska, op. cit., s. 36. 
administracyjnego jest przejawem ochrony zaufania obywatela do państwa i stanowionego prawa ${ }^{76}$. Zasada ta może stanowić jedno z głównych remediów wobec nadobfitości, niespójności, nieprzejrzystości i niestabilności unormowań prawa administracyjnego ${ }^{77}$.

mgr Eukasz Folak

Uniwersytet Jagielloński

lukasz.folak@doctoral.uj.edu.pl

\title{
THE PRINCIPLE OF PROPORTIONALITY IN THE CREATION \\ OF ADMINISTRATIVE LAW
}

\begin{abstract}
Sum mary
The subject of the article is the application of the principle of proportionality (the adequacy of the objective and the measure) in the creation of administrative law. Some issues that ought to be taken into account during the process of lawmaking have been analysed and the need to distinguish and apply the principle of proportionality in the legislative process in administrative lawmaking, necessary due to, among other things, the progressive inflation of the legislation of that field of law, the risk of inadequate interference with the subjective rights and the freedoms of the individual, and the need to correct and rational legislation have been discussed with references to philosophical concepts. Further, varied aspects of the discussed principle, including its vertical, horizontal, external (quantitative) and interior (qualitative) significance as well as the controlling aspect regarding the compliance with the principle in the lawmaking of administrative law, the broadest field of public law, have also been discussed.
\end{abstract}

\footnotetext{
${ }^{76}$ Orzeczenie TK z 9 stycznia 1996 r., K 18/95, OTK 1996, cz. I, CBOSA - http://orzeczenia. nsa.gov.pl/doc/4DE2660BDA.

77 Por. G. Szpor, Wzrost roli orzecznictwa a mankamenty legislacji, w: T. Bąkowski, K. Grajewski, J. Warylewski (red.), Orzecznictwo w systemie prawa, Warszawa 2008, s. 223-225.
} 
